\title{
The Path Choice of College Students' Ideal and Belief Education from the Perspective of New Era
}

\author{
Zhao Shili ${ }^{1, a^{*}}$, Zhang Chunyang ${ }^{2, b}$ \\ ${ }^{1}$ Chongqing College of Electronic Engineering, Shapingba, Chongqing, China \\ ${ }^{2}$ Chongqing College of Electronic Engineering, Shapingba, Chongqing, China \\ a1771839879@qq.com \\ ${ }^{b} 627902932 @ q q . c o m$
}

\begin{abstract}
Cultivating new people in an era with ideals, skills, and responsibilities is a new strategic plan for talents. and it is also a goal for talent training in colleges and universities. As the main body of the newcomers of the times, the primary task of young college students is to strengthen their ideals and convictions and build up their spiritual foundation. To this end (For this purpose), colleges and universities must carry out the theme education of ideals and beliefs of college students. By changing teaching concepts, designing teaching content, and using teaching platforms cleverly, the theory and practice, recessive and explicit, false reality, and pluralism are combined to promote the normality of ideals and beliefs education for college students. Institutionalization will introspect themselves as the "National Responsibility" for their spiritual pursuit and externalization as their conscious action.
\end{abstract}

Keywords: newcomers of the times, college students, ideals and beliefs, path selection

\section{时代新人视域下大学生理想信念教育的路径选择}

\author{
赵世丽 $1, \mathrm{a}^{*}$ ，张春阳 $2, \mathrm{~b}$
}

1 重庆电子工程职业学院, 沙坪坝, 重庆, 中国

2 重庆电子工程职业学院, 沙坪坝, 重庆, 中国

a1771839879@qq.com

${ }^{b} 627902932 @ q q . c o m$

\section{摘要}

培养有理想、有本领、有担当的时代新人是新的人才战略规划, 也是高校人才培养目标。青年大学生 作为时代新人的主体, 首要任务就是坚定理想信念、筑牢精神之基。为此, 高校必须要开展大学生理 想信念主题教育, 通过转变教学理念、精设教学内容、巧用教学平台等, 将理论与实践、隐性与显性、 虚实与多元结合, 推动大学生理想信念教育常态化制度化, 将担当“民族复兴大任”内省为他们的精神 追求, 外化为他们的自觉行动。

关键词：时代新人；大学生；理想信念；路径选择

\section{1. 前言}

“青年一代有理想、有本领、有担当，国家就有 前途，民族就有希望。”青少年阶段是人生的“拔节孕穗 期”, 也是理想信念生成的关键时期。大学生作为掌握 文化知识和专业技能的青年群体, 必须做具有坚定理想 信念和深厚爱国情怀，心系国家前途命运的时代新人。 就此而言, 立足新的历史方位, 高校从教学理念、教学
内容、阵地建设等全方位帮助大学生坚定理想信念、补 足精神之钙, 引导他们在进行伟大斗争、建设伟大工程、 推进伟大事业、把个人理想镌刻在奋力实现中华民族伟 大复兴征程上。

2. 厘清理念: 能力与素养同行

当今时代, 经济稳中向好, 科技推陈出新, 知识更 
新人; 而信仰信念引领道德追求, 筑牢理想信念之基是

新周期缩短, 消息错综复杂, 这为大学生提供了更大的 舞台、更宽的道路施展才华、出彩人生; 也对大学生的 能力和素养提出了更严苛的要求。在此背景下, 大学生 除了要努力掌握文化知识和专业技能, 打牢知识根基, 练就过硬本领; 更要懂得“思想是行动的先导”, 树牢价 值标杆, 锤炼高尚的人格, 坚定对马克思主义的信仰、 对中国特色社会主义的信念, 用习近平新时代中国特色 社会主义思想武装头脑, 指导行动。

\section{1 善用“以生为本”思想统筹理想信念教育}

教育之根本要务即“培养什么人, 怎样培养人, 为 谁培养人”。高校时代新人的理想信念教育, 必须贯彻 “以生为本”理念, 结合当代大学生的个性特点, 满足大 学生发展的需要, 消解大学生的认知困惑, 帮助大学生 树立正确的世界观、人生观和价值观。

第一, 突出学生的主体性。马克思视阈下, 人类所 有活动都有动机和需求, “人们奋斗所争取的一切, 都 同他们的利益相关”, 教育的出发点亦是满足学生的需 要。大学生是高校理想信念教育的对象和参与者, 其合 理化的需求必须得到充分的尊重和认可。大学生理想信 念的培育必须基于他们的实际, 确保教育内容的针对性 和实效性, 让理想信念教育真正入脑入心, 成为学生发 展的动力源和涅槃石, 成为时代新人的助推器。

第二, 尊重学生的差异化。身处新时代的 90 后、 00 后大学生, 受家庭教育、社会环境等因素影响, 思维 更加活跃、需求更加独特、观点和看法更加多元。正如 马克思所言: “人们的意识, 随着人们的生活条件、人 们的社会关系、人们社会存在的改变而改变。”可见， 大学生理想信念教育需要高校和教育者“对症下药”，打 破传统的千篇一律的教育模式, 在充分了解学生认知困 惑和价值迷茫的前提下, 遵循他们个性化成长需要, 针 对学生心理特点, 因材施教, 进行差异化引导, 让理想 信念教育真正服务于全体大学生。

第三，加强学生的正面引导。高校将“以人为本”的 理念贯穿于理想信念教育全过程, 不仅要尊重学生基于 个人利益进行的价值选择; 更要强化树立崇高理想信念 的重要性, 帮助大学生树立远大的理想抱负, 将个人的 前途与国家的未来结合, 将个人的理想同中国梦衔接, 争做新时代的浪潮儿。

\section{2 以立德树人为抓手扎实开展理想信念教育}

十八大以来, 习近平总书记紧扣立德树人根本任 务, 提出了诸如“没有理想信念, 精神上就会“缺钙”; 一 个国家要同心同德迈向前进, 必须有共同的理想信念作 支撑” 等论述。进一步诠释了要将理想信念作为高校立 德树人的“灵魂”工程, 强调以培养时代新人为目标, 凸 显了理想信念在立德树人关键环节中的重要作用。

《新时代公民道德建设实施纲要》强调, 要不断提 升公民道德素质, 培养和造就担当民族复兴大任的时代
培养时代新人的首要任务。总的说来, 高校立德树人和 大学生理想信念教育都是以“学生”为旨规, 其逻辑起点 可谓是“不约而同”; 它们都是为了回答“为谁培养人”以 及“培养什么样的人”的根本性问题，两者在目标和方向 上可谓“殊途同归”; 此外, 高校立德树人和大学生理想 信念教育都能够武装大学生头脑、抵御错误思潮、维护 意识形态安全，在价值向度上“异曲同工”。

如今, 聚焦全员全过程全方位育人, 许多高校着力 构建“三全育人”新格局, 取得了显著成效。大学生理想 信念教育必须同“三全育人”模式对接起来，融入教育全 过程, 贯穿于课堂、实践、科研等方方面面, 渗透在管 理者、教师、学生等各个主体, 齐抓共管形成合力。

\section{3 用新时代人才培养要求落实理想信念教育}

“功以才成, 业由才广。”人才是解决新时代不平衡 不充分问题、最终实现中国梦的关键; 创新驱动的实质 是人才驱动; 综合国力竞争说到底是人才竞争。党中央 历来重视人才培养工作，从党的十九大报告提倡“三有 青年”到 2018 年全国教育大会提出六个“下功夫”, 培养 符合新时代需要的人才始终是永恒的课题。

无论是“有理想、有本领、有担当”的成才观；还是 培养人要在“坚定理想信念、厚植爱国主义情怀、加强 品德修养、增长知识见识、培养奋斗精神、增强综合素 质”上下功夫。习近平总书记都为新时期人才培养提出 了新标准, 并将坚定理想信念放在首要位置。也正是为 了坚定理想信念, 大学生必须提高自己的学识, 厚植自 己的爱国情怀, 增强自己的责任意识, 为国家的前途和 发展贡献自己的才干。

青年大学生, 必须结合新时代人才培养的需求和高 校人才培养方案, “立鸿鹄志, 做奋斗者; 求真学问, 练真本领; 知行合一, 做实干家”。才能担当起祖国的 期望、历史的重任、人民的重托，成长为符合时代需要 的社会主义建设者和接班人。

\section{3. 精设内容：传承与创新并存}

首先, 大学生理想信念教育的内容具有针对性, 即 要从学生的实际出发, 着力推进“三因三律”教学内容。 其次, 大学生理想信念教育的内容具有历史性, 这就要 求我们善于从中华优秀传统文化中汲取营养。再次, 大 学生理想信念教育具有时代性, 必须结合当前的实际, 将“死板”的教材内容转化为“鲜活”的教学题材。

\section{1 着力推进“三因三律”的教学内容}

大学生理想信念教育的内容只有坚持“三因”（“因 事而化、因时而进、因势而新”)，遵循“三律”（“思想 政治工作规律，教书育人规律，学生成长规律”），才 能切实提升大学生理想信念的时代感和获得感。 
生尤其是大学生党员抵御错误思想侵蚀、坚定正确三观 的“护身符”和“防火墙”。

党团日活动是高校开展思想政治工作的有效补充, 它通常以鲜明的主题、丰富的内容、多样的形式开展活 动, 对坚定大学生的理想信念发挥着举足轻重作用。显 而易见, 党团日活动不同于一般的文体活动, 它必须遵 循党的基本路线、方针和政策的指导, 帮助大学生了解 国情、世情和党情; 还可以把专业知识融入党团日活动, 将专业知识生活化, 找准学生学习的兴趣点, 使他们在 接受理论学习的同时潜移默化的接受理想信念教育。鉴 于此, 大学生理想信念教育, 可以结合大学生的心理生 理特点, 创新主题党团日活动内容, 围绕“我的人生信 条”, “如何看待理想和现实的矛盾” “人人梦与中国梦” 等主题, 采取学术讲座、知识竞赛、演讲辩论、实地参 观等大学生喜闻乐见的形式, 引导大学生在实际体验中 反思自我、完善自我, 明晰并坚定正确的理想信念。

实践证明, 高校以开展主题教育为契机, 将大学生 理想信念教育与主题教育对接起来，有利于他们在学习 中接受灵魂的洗礼，提升政治自觉，担当自己的职责使 命, 发扬埋头苦干的精神; 并在常态化的学习和规范化 实践中共筑思想防线。

\section{4. 拓宽路径: 虚实与多元耦合}

时代新人视阈下, 大学生理想信念教育必须关心学 生所需、彰显时代特征, 通过整合现有资源, 拓宽大学 生理想信念教育的路径。具体而言, 可以通过课堂教学 “主”渠道、信息网络“新”平台、校园环境“隐”课堂、社 会实践“活”土壤等提高大学生理想信念教育的实效性, 培育具有坚定理想信念的“时代新人”。

\section{1 夯实课堂教学“主”渠道}

高校开展理想信念教育, 要充分运用课堂教学主渠 道, 帮助大学生树立远大理想。各门课程都要“守好责 任田”，尤其是促进思想政治理论课与各类课程形成协 同效应，同向同行满足学生成长发展的需求和期待。

思想政治理论课（以下简称“思政课”）是大学生理 想信念教育的“关键课程”，对大学生理想信念教育起关 键作用。因而, 高校要加强“关键课程”的改革, 创新教 学内容、改进方式方法、革新课程评价等, 淘汰“水课”、 打造“金课”, 切实把大学生理想信念的培育融入思政课 教学全过程, 提高大学生理想信念教育的质量。目前, 高校思政课教学可以采取专题研讨的形式, 加强学生互 动, 调动学生学习的积极性和主动性, 促进大学生理想 信念知信行相统一。

除此之外, 还要注意运用课堂教学的引导效用, 促 进其他课程与思政课程同向同行, 共同培育大学生理想 信念。新时代背景下, 要培养德才兼备的时代新人, 就 必须扭转大学生理想信念教育在非思政课中相对薄弱 的现状, 深入推进课程体制改革。为此, 要积极挖掘其 
成的价值取向、思维方式、精神气质, 包括办学理念、 大学精神、校园历史、校风校训等。将大学生理想信念 教育巧妙融入校园文化精神中, 依托学校宣传栏、宣传 榞窗、阅报栏论坛等进行传播, 使大学生在校园文化精 神中接受耳濡目染的教化。再次, 注重以文化人、以文 育人, 还要引导大学生开展格调高雅而又特色鲜明的校 园文化活动, 将大学生理想信念教育贯通其中, 打造校 园文化品牌活动。通过校园文化活动凝心聚力, 因势利 导学生的观点、意识和行为。

在互联网“包罗万象”的时代, 移动互联已然成为大 学生学习、生活、娱乐的新场域, “网络+教育”已是大 势所趋。一方面, 信息网络为大学生理想信念教育提供 了新载体、新渠道, 创新了大学生理想信念教育的培育 方式; 另一方面, 网络信息良莠不齐、鱼龙混杂, 使得 学生难辨真假, 可能发生散播谣言的行为, 给理想信念 教育带来新挑战。于是乎, 教育工作者必须主动占领网 络“新”平台, 完善校园网络监管机制, 清除负面资讯, 净化网络空间, 引导学生文明上网。

习近平总书记强调, 要运用新媒体新技术使工作活 起来。网络作为一种新兴媒介, 具有知识丰富、层次分 明、传播及时、互动性强等优势, 成为理想信念教育的 重要阵地。高校可以利用好 $\mathrm{QQ}$ 、微博、微信、论坛等 受热捧的软件, 利用公众号及时推送弘扬主旋律、传播 正能量的文章, 为大学生理想信念教育增添色彩和温 度。大力宣传学习强国、学习大国、学习通等学习平台, 深入学习贯彻习近平新时代中国特色社会主义思想, 学 习模范代表人物, 牢牢掌握网络意识形态主导权。

高校可以创建理想信念专题网站, 开设研讨互评栏 目, 宣扬理想信念相关内容和先进人物事迹, 使大学生 能够利用健康的网络环境, 了解相关方面的权威知识; 通过更生动的画面、更通俗的语言, 愈加直观的理解理 想信念教育的精髓。大学生在掌握必要的理想信念知识 的基础上, 借助网络媒体强大的传播能力和吸引能力, 可以影响带动更多人, 形成联动效应, 实现“网络+理想 信念教育”的有效全覆盖。

\section{3 丰富校园生活“隐”课堂}

校园是师生学习、生活的场所, 校园生活对学生思 想道德素养和个人行为塑造发挥着强大作用。“大学非 大楼之谓也, 有文化之谓也”, 大学不仅只有良好的建 筑群, 关键是要有文化底蕴, 对大学生理想信念的培育 起“润物细无声”渗透和熏陶作用。

坚定大学生理想信念, 需要重视校园文化隐教育, 大力营造“和谐美丽”的校园环境、挖掘“匠心独具”的校 园精神、开展“精彩纷呈”的校园活动。首先, “一所好 的学校墙壁会说话”, 恢弘大气的建筑物、庄重静烅的 图书馆、书声琅琅的教学楼等, 共同营造出良好的文化 氛围, 这不仅有利于学生的学习和生活, 而且能够提升 大学生的思想道德素养, 助力个人成长。其次, 借力校 园文化“雪落无痕”的渗透作用, 挖掘其潜在的理想信念 内容。校园文化精神是一所学校在长期的历史过程中形

\section{4 融入社会实践“活”土壤}

“道虽迩，不行不至；事虽小，不为不成”，正确的 理想信念无一不是在具体的实践中养成。通过开展系列 社会实践活动, 将理论与实际、校园与社会、学习与服 务等结合, 去真实感知历史和现实, 切身体会到信念信 仰的力量, 增强对马克思主义理论的认同和信仰。

教育过程本身就是实践过程, 要把社会实践当作理 想信念教育的生动课堂, 把理论教学投入社会实践第一 线, 让学生在实践中去感知与认识。一是开展特色实践 教学。思想政治理论课与大学生社会实践相结合, 组织 大学生参加思想政治理论课实践研修, 投身“三下乡”实 践活动, 缅怀革命先烈调研活动等, 发挥思政实践课育 人的作用。党团组织利用建军节、国庆节等重要纪念日, 带领学生参观红色文化遗址, 引导大学生正确认识中国 革命、建设、改革的艰难历程, 以此来约束自己的言行 举止。二是完善志愿服务体系。号召大学生多参加志愿 服务活动, 推进志愿服务进学校、进社区、进医院、进 车站等, 加快实现志愿服务阵地全覆盖, 让志愿服务发 挥典型示范作用, 扩大理想信念教育的影响面和亲和 力。三是抓好专业实习。众多高校立足实际, 紧紧围绕 人才培养目标, 积极开展校企合作、协同育人。凭借这 一模式, 学生可以到合作基地参观智能设备、先进技术 和完整流程, 让学生感知强大的“中国精神”催生的“中 国奇迹”; 学生也能够利用寒暑假到企业实习, 知行合 一, 让理想信念教育真正落地, 实现大学生理想信念教 育从理论到实践回归理论, 这样一个循环往复的过程。 大学生理想信念教育融入社会大环境, 就是通过基 地参观、志愿服务、专业学习、实习见习等到达育人效 果, 在此过程中可以折射出大学生有理想、有本领、有 担当的精神风貌。

综上所述, 高校围绕“培养什么人, 怎样培养人, 为谁培养人”的问题, 聚焦理想信念在实现伟大复兴、 践行核心价值观、公民道德建设中的重要性, 积极探索 大学生理想信念教育的有效路径, 将大学生凝聚在中国 特色社会主义伟大旗帜之下, 拧紧新时代大学生的“总 开关”, 用“青春梦”托起“中国梦”, 奋力谱写无愧于新时 代和人民的瑰丽篇章。 


\section{项目基金}

本文为重庆电子工程职业学院 2020 年度校级一般 项目《习近平青年观视间下大学生理想信念教育常态 化、制度化研究》（XJSK202006）的阶段性成果之一。

\section{REFERENCES}

[1] Xi Jinping. Decided to build a well-off society in an all-round way Capture the great victory of socialism with Chinese characteristics in the new era-Report at the 19th National Congress of the Communist Party of China [M]. Beijing: People's Publishing House, 2017: 707.

[2] The Complete Works of Marx and Engels (Vol. 1) [M]. Beijing: People's Publishing House, 1956: 82.

[3] Anthology of Marx and Engels (Vol. 1) [M]. Beijing: People's Publishing House, 1995: 291.

[4] Xi Jinping: Speech at Peking University Teachers and Students Forum [EB / OL]. Xinhuanet.

Http://www.xinhuanet.com/2018-05/03/c_1122774230. htm, 2018-05-03.

[5] Xi Jinping emphasized at the National College Ideological and Political Work Conference: Integrating ideological and political work throughout the entire process of education and teaching to create a new situation for the development of higher education in China [N]. People's Daily, 2016-12-09.

[6] Tang Su'e, Liu Liquan. Research on the Improvement of Network Literacy of Ideological and Political Workers in Colleges and Universities [J]. Research in Ideological Education, 2017, (06). 